Marquette University

e-Publications@Marquette

Theology Faculty Research and Publications

Theology, Department of

$1-1-2015$

\title{
Actual Grace and the Elevation of the Secular
}

Robert M. Doran

Marquette University, robert.doran@marquette.edu

Published version. Australian eJournal of Theology, Vol. 22, No. 3 (2015): 166-179. Permalink. (C) 2015 Australian Catholic University. Used with permission. 


\title{
Actual Grace and the Elevation of the Secular
}

\author{
Robert M. Doran
}

\begin{abstract}
This paper develops and integrates several strands of thought represented in recent contributions that the author has tried to make to the secularizationsacralization debate. ${ }^{1}$ That debate is both ecclesial and theological, and the two contexts are related. The theological debate will not be resolved short of discovering the key to discerning grace everywhere. Resolution of the ecclesial debate will take much longer, if not in the sensus fidelium at least in magisterial attitudes. This paper proposes a central element in the relevant discernment.
\end{abstract}

Key words: Sacralization, secularization, actual grace, Bernard Lonergan, René Girard, Charles Taylor, Law of the Cross, new evangelization

\section{Sacralizations and SeCularizations Welcomed and Resisted}

I

n a lecture delivered at Trinity College, University of Toronto, in November 1973, "Sacralization and Secularization," Bernard Lonergan proposed the complex heuristic structure of (1) a sacralization to be dropped, (2) a sacralization to be fostered, (3) a secularization to be welcomed, and (4) a secularization to be resisted. ${ }^{2}$ In the first volume of The Trinity in History, I provided "lower-blade" suggestions meant to give flesh to that structure. ${ }^{3}$ I wish to reorder and rework the proposals found there, though the reader should turn to that longer treatment for further details.

I propose to start with "a sacralization to be fostered" and "a secularization to be welcomed." This is in line with my growing conviction that positions should be advanced before counterpositions are reversed, that the views of others should be made better than they really are if one is to foster genuine dialogue. Fostering true sacralization will counteract various forms of deviated transcendence and so will facilitate the dropping of false sacralizations. And welcoming genuine secularization will entail resisting secularism; for genuine secularization is the fruit of attentiveness, intelligence, reasonableness, and responsibility, while secularism depends on neglecting or denying the finality, the

\footnotetext{
1 See Robert M. Doran, "Lonergan and Girard on Sacralization and Desacralization," Revista Portuguesa de Filosofia 63 (2007): 1171-1201, available in revised form in Robert M. Doran, Essays in Systematic Theology: An E-book, www.lonerganresource.com, Essay 24; The Trinity in History: A Theology of the Divine Missions, vol. 1: Missions and Processions (Toronto: University of Toronto, 2012) chapter 10 passim; "Invisible Missions: The Grace That Heals Disjunctions," to be published in Seekers and Dwellers: Plurality and Wholeness in a Time of Secularity, ed. Philip J. Rossi. This volume will be part of Cultural Heritage and Contemporary Change, Series VIII: Christian Philosophical Studies, published by The Council for Research in Values and Philosophy, Washington, DC.

2 See Bernard Lonergan, "Sacralization and Secularization," in Philosophical and Theological Papers 1965-1980, vol. 17 in Collected Works of Bernard Lonergan, ed. Robert C. Croken and Robert M. Doran (Toronto: University of Toronto, 2005) 259-81.

3 Doran, Missions and Processions, chapter 10.
} 
upwardly but indeterminately directed dynamism, of such authentic intentionality, which ultimately is obediential potency for the gift of a share in divine life. Such neglect or denial sooner or later cuts short even the potential of the native spirit of human inquiry.

I want to suggest that the key to discerning the genuine sacred in human history lies in what Lonergan calls the just and mysterious Law of the Cross, particularly as the redemptive action of returning good for evil informs a praxis that works strenuously to implement the integral scale of values and so to extend the formal effects of grace to the realms of cultural and social values. ${ }^{4}$

Discerning the genuine sacred in history thus entails recognizing, implementing, and celebrating the transformation of evil into a greater good, indeed the supreme good of transformed human relations, precisely through the determination to absorb evil in love like a blotter and to respond with forgiveness. ${ }^{5}$ This is the mind of Christ Jesus, which Philippians 2 enjoins us to "have in us."

The Law of the Cross was revealed progressively in the Israelite scriptures, where it reached its highest expression in the servant songs of deutero-Isaiah. It is embodied fully in the Incarnate Word, Jesus of Nazareth. As thus revealed, it is a specification or objectification of a genuine religious component that can be found in other religious traditions and in graced secular living. I wager that it is more clearly differentiated progressively in the Hebrew Bible than elsewhere, and that it appears definitively in the New Testament. But fidelity to this Law can be found everywhere, even if it often remains a coincidental departure from violent schemes of recurrence. What is specific to Christianity are the mysteries of the Incarnate Word and the Trinity, and part of what is specific to the Incarnate Word as embodying a Trinitarian mission is that in him there is revealed and so made known this law of utmost generality, a law that affects the very constitution of history. This reality, wherever it is found, is determinative of the genuine religious word, as that word affects historical action or praxis through the development and purification of cultural values. Any word that would purport to be religious but that runs counter to or neglects this dimension of returning good for evil is fraudulent, a manifestation of deviated transcendence, no matter what "sacred" authority utters it. The revelation in the incarnate Word of God sets the standard for the genuine religious word everywhere.

The key to secularizations to be welcomed in the conduct and organization of human affairs lies in the precepts of Lonergan's generalized empirical method: Be attentive, Be intelligent, Be reasonable, Be responsible. The natural law consists in fidelity to those precepts. My proposal regarding a psychic conversion to be added to Lonergan's

\footnotetext{
${ }^{4}$ For the basic dynamic structure of the scale of values see Theology and the Dialectics of History (Toronto: University of Toronto, 1990, 2001) chapter 4 and passim. For the Law of the Cross, see Bernard Lonergan, De Verbo incarnato (Rome: Gregorian University, 1964) thesis 17; to be published with English translation in Bernard Lonergan, The Redemption, vol. 9 in Collected Works of Bernard Lonergan, trans. Michael G. Shields, ed. Robert M. Doran and H. Daniel Monsour (Toronto: University of Toronto).

5 Bernard Lonergan, "The Mediation of Christ in Prayer," in Philosophical and Theological Papers 1958-1964, vol. 6 in Collected Works of Bernard Lonergan, ed. Robert C. Croken, Frederick E. Crowe, and Robert M. Doran (Toronto: University of Toronto, 1996) 182: "the fundamental theorem, as it were, is transforming evil into good, absorbing the evil of the world by putting up with it, not perpetuating it as rigid justice would demand. And that putting up with it acts as a blotter, transforms the situation, and creates the situation in which good flourishes."
} 
religious, moral, and intellectual conversion leads me to affirm that there is also a dimension of mood or disposition or affect that precedes, accompanies, is transformed by, and goes beyond the operations performed by the attentive, intelligent, reasonable, and responsible subject. ${ }^{6}$ This affective or psychic dimension is appealed to in what Christian tradition calls discernment. The natural orientation of the human spirit to intelligibility, the true and the real, and the good, and to beauty as the splendor and fulfilment of these objectives, and the affective dispositions that match this orientation, will disclose over time and over the development of human culture cultural and social arrangements that can and should be granted autonomy from the mantle of sacral authority. ${ }^{7}$ If sacral authority is itself determined as authentic only by fidelity to the Law of the Cross and not by the deviated transcendence of darkly sacrificial religiosity or by the false mantle of authoritarian preaching masking itself as proclamation of the gospel, there will be no conflict between genuine sacralization and authentic secularization. The secularization of cultural life and social institutions will continue to encourage the influence of genuine religious and personal values in the same cultural and social spheres, even while increasing its indictment of false sacralizations. Genuine secularization has no problem with returning good for evil, and returning good for evil is the determinant of what truly is sacred in historical relations. Moreover, as Lonergan makes abundantly clear, sustained fidelity to the precepts of generalized empirical method is possible only by the gift of God's love, whether recognized or not, and so only by some lived participation in the genuine sacred, and so in the love embodied in the Law of the Cross.

With this stress on positions to be advanced, we may turn to the antithetical considerations of sacralizations to be dropped and secularizations to be resisted. The reversal of these existential counterpositions will be relatively easy once fidelity to the existential positions of sacralizations to be fostered and secularizations to be welcomed is more or less securely in place.

Sacralizations to be dropped in the conduct of human affairs entail any and all attempts to employ the name or word of God or any other sacral trappings to justify violence or otherwise to distort the scale of values, especially at the level of social values, where persecution, exclusion, and scapegoating not only of carriers of the genuine religious word but also of anybody else easily occurs. There is neither Jew nor Greek, male nor female, rich nor poor, straight nor gay, white nor person of color, and if there is, and if the existence of such exclusions is based in some religious word, that word itself is inauthentic, and the sacralization of activities and groups based on such a word must be dropped. On this basis, the Catholic Church will be coaxed by divine grace to drop many false sacralizations in the next while. To the extent that the Church is faithful to the sacralizations to be fostered and the secularizations to be welcomed, the dropping of these instances of deviated transcendence will be relatively easy. If they prove difficult, it will be due to resistance to the sacralizations to be fostered and the secularizations to be welcomed, that is, resistance to the Law of the Cross through which redemption is brought to the human world.

\footnotetext{
${ }^{6}$ On psychic conversion see chapter 2 in Doran, Theology and the Dialectics of History.

${ }^{7}$ I propose that the shifting constitutive meaning of the social institution of the family is a case in point. Criteria need to be developed for determining which marriages are truly sacramental, truly a matter of "what God has joined together," truly supernatural in their origin.
} 
Secularizations to be resisted are almost all based in efforts to locate human "coming of age" as a perfection to be attained exclusively in this life and exclusively on the basis of human resources. They often but not always are indistinguishable from sacralizations to be dropped, since the latter often originate in a neglect of the invitation of grace to acquiesce to the gift of God's love always offered. Pope Francis has indicated as much in his denunciations of clericalism, which represents simultaneously a sacralization to be dropped and a secularization to be resisted. Much deviated transcendence is a coverup for the rejection of genuine transcendence in humble, self-sacrificing love.

The four points that I am making are a theological elaboration of Matthew 25's implicit doctrine on grace present in the historical and secular order. "As often as you did it or did not do it to these, the least of my brothers and sisters, you did it or did not do it to me." No sacramental incorporation into the church is required to fulfill these demands, and if such incorporation is employed to skirt these demands, it manages only to create a false sacralization, a case of deviated transcendence, precisely the sort of thing that Jesus railed against in a different religious context in his diatribes concerning the scribes and the Pharisees, the lawyers, and the high priests: the official religious authorities of his day.

Lonergan's articulation of the Law of the Cross mentions a supreme good into which the "evils of the human race" are transformed. That supreme good is a new community in history and in the life to come, the whole Christ, Head and members, the communion of saints, in all its concrete determinations and relations.

The Law of the Cross enjoins, I believe, a three-stage developmental process: nonretaliation, forgiveness, and reconciliation. The last step, reconciliation, depends on the acknowledgment by all parties of the truth of what has happened. Moreover, the supreme good may be regarded as the form of the economy of salvation introduced into the matter of a human race infected with original sin, burdened with actual sins, entangled in the penalties of sin, alienated from God, and divided both within individuals and between them. It is in effect an elevation of human relations to participation in the divine relations. ${ }^{8}$ But, like every form, its emergence is in accord with probabilities, and in this case the probabilities "regard the occurrence of [our] intelligent and rational apprehension of the solution and [our] free and responsible consent to it." 9 Those probabilities are greatly increased by God's revelation of the dynamics of the solution, a revelation that is progressive and cumulative over the history of Israel and fulfilled in the visible mission of the Word, but that always will need to be appropriated anew in the concrete circumstances of history.

That "form" takes shape on the basis of a fourfold communication of God to us (in the hypostatic union, the uncreated gift of the Holy Spirit and the reciprocal movement of charity, and hope for the fulfilment of human natural desire that in fact is given with the beatific vision). Consequent on these gifts is a developing order of personal relations brought about through apprehension of the divine self-communication (faith) and the

\footnotetext{
8 This will be one of the principal points argued in the second volume of The Trinity in History, a volume subtitled Missions, Relations, and Persons.

9 Bernard Lonergan, Insight: A Study of Human Understanding, vol. 3 in Collected Works of Bernard Lonergan, ed. Frederick E. Crowe and Robert M. Doran (Toronto: University of Toronto, 1992) 720.
} 
charity flowing from that apprehension. ${ }^{10}$ The form is really the communion of saints, a community of friendship with the three divine persons and among ourselves. Lonergan's emphasis on a new community, a new social reality, as the supreme good into which the evils of the human race are transformed corresponds to his position regarding the state of grace. The state of grace is a social, interpersonal situation grounded in the three divine subjects of the one consciousness of God. The fourfold communication of God is an imitation of and participation in the divine relations, and so a mimesis that runs counter to the infected mimesis that constitutes or at least profoundly affects the evils of the human race from which we are freed by the Law of the Cross.

Talk of mimesis brings to mind the work of René Girard, who in my estimation has discovered something very important about the "evils of the human race" that are transformed into this new community of human and divine subjects. These evils are often distortions of relations hindering genuine community from ever being realized, and Girard has pinpointed a basic dimension of that distortion.

Lonergan's well-known treatment of these evils speaks of "basic sin" and "moral evil," where "basic sin" is the failure to reject a morally reprehensible act or to perform a morally obligatory one, and "moral evils" are the consequences of basic sin, including deteriorating relations, systemic injustices, and bias of several kinds. ${ }^{11}$ These evils are transformed by the law of the cross into a new community.

These evils are of course all traced ultimately to original sin. And so with Girard I ask to what extent we may associate original sin with submission to a mimetic temptation. To what extent may we fruitfully regard peccatum originale originans as an original and originating failure to reject the mimetic cycle represented in the temptation "You shall be like God" (Genesis 3.5), and peccatum originale originatum as a violent cycle unleashed by that original failure, as is manifested in the portrayal of the first murder in Genesis as also entailing a similar failure to reject infected mimesis?

I ask as well to what extent what Lonergan calls basic sin in our own lives may fruitfully be understood as a matter of failing to reject infected mimesis. Is that failure one instance of basic sin, or is it more than that, perhaps the core of this basic root of irrationality in human rational consciousness?

I ask, again, to what extent the moral evils that follow upon basic sin (the deterioration of human relations, the systematizing of injustice, and the elevation of various forms of bias to the determining principles of human affairs) are consequences of failing to reject the mimetic cycle, and conversely to what extent the satanic sequence of events that follows from failing to reject the mimetic cycle is coincident with the consequences of basic sins that constitute moral evil.

Furthermore, "to what extent do the biases that are structural elements in these consequences predispose us to further failures to reject the mimetic cycle?" 12 "Girard, by filling in a heuristic structure provided by Lonergan, helps us specify the evils of the

\footnotetext{
${ }^{10}$ For a detailed account see Missions and Processions, chapter 2.

11 Lonergan, Insight 689.

12 Doran, Missions and Processions 235.
} 
human race that are transformed, and ... Lonergan is clearer on the reality into which these evils are transformed." 13 The heuristic structure to which I refer is the three-step dynamic of the Law of the Cross: (1) from basic sin to moral evil, (2) non-violent response that returns good for evil, (3) the transformation of the evil into a greater good.

The structure of the Law of the Cross, then, may be phrased in a way that complements Lonergan with Girard. Jesus (1) suffered and died because of the basic sin, the failure of will, that brought him to this point, a failure that entailed massive distorted mimesis. He (2) transformed the evil of suffering and death, accepted in love and obedience, into a supreme moral good, a new community emergent from these events, the whole Christ, Head and members, in all their concrete relations and determinations, which were entirely different from the relations and determinations that preceded this event. And God the Father (3) raised him from the dead as the first-born into this new community of "the whole Christ, Head and members." 14

The way in which the Law of the Cross is observed in Christ is of course quite different from the way it is observed in the members. It appears in Christ as in the redeeming principle, and in the members as in what is to be redeemed; we have to learn and believe, and come freely to consent to Christ, living in him, operating through him, being associated with him, so that we may be assimilated and conformed to him in his dying and rising. A fuller theology would regard these as formal effects of participating in and imitating active and passive spiration through sanctifying grace and charity, which, precisely because of this connection, may always be regarded as "the grace of Christ." 15

What catalyzes the transition to a new social situation, however, is the authentically religious word, a word shot through with the soteriological differentiation that acknowledges that the solution to the problem of evil is to render good for evil done. This dimension is progressively revealed by God, through the Israelite and Christian scriptures, as what really is holy and so sacred in human history.

Within firm parameters set by the natural law of human interiority, by its supernatural fulfilment, and by the Law of the Cross as constituting the reality of what is genuinely sacred in human history, it may be said that what is perhaps most intelligently regarded as a sacral domain at one stage of religious development can be secularized. There may, for instance, be a quite legitimate point to surrounding economies, polities, family arrangements, and legal institutions with some sacral trappings when civilizations are in decline or when new civilizations are just beginning to emerge. But such a sacralization will be challenged as people grow and develop. Sacral domains can also be desacralized, and one wonders whether Jesus himself did not foster that process in many of the things he is reported to have said about the religious priorities of some of the teachers of Israel. Again, what seems to be secular activity can be given a genuine religious significance. "As often as you did it for the least of these, you did it for me" (Matthew 25.40). Finally, one style of religious development may be defective in comparison with another style. "When you pray, do not imitate the hypocrites, for they love to say their prayers standing up in the synagogues and at the street corners for people to see them ...

\footnotetext{
13 Ibid. 236.

14 See ibid. 237.

15 See ibid. chapter 2 .
} 
But when you pray, go to your private room and, when you have shut your door, pray to your Father who is in that secret place" (Matthew 6.5-6).16

The ultimate criterion has to be located in the authenticity of the person, understood both philosophically and theologically.

the authenticity of self-transcendence, measured by the standards of cumulative attentiveness, intelligence, reasonableness, and responsibility, with all of these preceded, accompanied, and transcended by a movement of life promoted and sustained by the grace that is the gift of God's love, is the key to the authenticity of traditions, to collective as well as individual responsibility, and to both healing and creating in history. These social and cultural realities are objectifications of the concrete universal that is the normative subject. Again, since the gift of God's grace is required for sustained fidelity to these standards, the truly sacred is the source of all genuine development, even when genuine development entails a secularization of a domain of life that had previously been sacralized. The relations among the various levels in the scale of values are such that religious values condition personal authenticity, personal authenticity provokes cultural development, cultural development enhances the social good of order, and the social good of order promotes the equitable distribution of vital goods. Thus, no genuine secularization is an abandonment, only a refinement, of authentic religion. ${ }^{17}$

For Lonergan this context of development is best expressed in the language of (1) minor and major authenticity and unauthenticity, and (2) legitimate assurance regarding the genuineness of our religious convictions. Minor authenticity is measured by one's fidelity to one's cultural or religious tradition; major authenticity is measured by the integrity of the tradition itself. In the long run, one must fall back on the criteria of personal authenticity promoted and sustained by the gift of God's love and revealed in the Law of the Cross.

\section{Questions Posed by Vatican II and Pope John Paul II}

The structure just reviewed enables us, I believe, to respond to questions explicitly raised by Vatican II's Pastoral Constitution on the Church in the Modern World (Gaudium et Spes) and by Pope John Paul II regarding the presence of Christ's grace outside the formal bounds of the church.

The Second Vatican Council raised questions that it did not answer. One of these was raised in section 22 of Gaudium et Spes. ${ }^{18}$ First, the text emphasizes the revelatory function of the visible mission of the Word. "It is Christ, the last Adam, who fully discloses humankind to itself and unfolds its noble calling by revealing the mystery of the Father and the Father's love." That revelatory mission is redemptive. "[B]y his incarnation the Son of God united himself in some sense with every human being" (GS 22). Second, however, if this is the case, the Council must admit, as it does, that it is not only Christians who receive "the first fruits of the Spirit" (Romans 8.23), which enable them to fulfil the law of love. Rather, Gaudium et Spes asserts, "This applies not only to Christians but to all

\footnotetext{
16 Ibid. 242-43.

17 Ibid. 243.

${ }^{18}$ From the translation by Norman Tanner (ed), Vatican II: The Essential Texts (New York: Crown Publishing Group, 2012).
} 
people of good will in whose hearts grace is secretly at work. Since Christ died for everyone, and since the ultimate calling of each of us comes from God and is therefore a universal one, we are obliged to hold that the Holy Spirit offers everyone the possibility of sharing in this paschal mystery in a manner known to God" (GS 22, emphasis added).

The council is affirming a doctrine-"the Holy Spirit offers everyone the possibility of sharing in this paschal mystery"-but in the words "in a manner known to God" it is suggesting a systematic-theological question: How can this be?

The same combination of a doctrinal affirmation of the universal offer of the Holy Spirit and a systematic question as to how the doctrine is to be understood appears in two encyclicals of Pope John Paul II, Redemptor hominis and Redemptoris missio. "This [the Council's affirmation] applies to everyone, since everyone is included in the mystery of Redemption, and by the grace of this mystery Christ has joined himself with everyone for all time ... Every individual, from his or her very conception, participates in this mystery ... Everyone without exception was redeemed by Christ, since Christ is somehow joined to everyone, with no exception, even though the person may not be conscious of it" (Redemptor hominis, $\S 13,14$ ). ${ }^{19}$ Again, "Universality of salvation does not mean that it is given only to those who believe explicitly in Christ and join the Church. If salvation is meant for all, it must be offered concretely to all ... The salvation of Christ is available to them through a grace which, though relating them mysteriously with the Church, does not bring them into it formally but enlightens them in a way adapted to their state of spirit and life situation" (Redemptoris missio, §10). ${ }^{20}$

\section{Aquinas on Actual Grace}

Valuable hints toward answering the question, "how can this be?", may be found in texts of Aquinas that Lonergan interpreted in his doctoral dissertation. In a sense the breakthrough text for Lonergan in the history of Thomas's views on what would come to be called actual grace is the relatively early text De veritate, q. 27, a. 5. Here, in contrast with his position in the commentary on the Sentences and, it would seem, even with his position earlier in the De veritate, which we know was written over a number of years, Thomas does not limit gratia gratum faciens, the grace of justification, sanctifying grace, to the habitual grace infused in baptism. Consequent upon the discovery of the theorem of the supernatural, this baptismal grace, as Lonergan insists, was important in resolving difficulties in medieval theology. But Thomas writes, "The grace that makes one pleasing is understood in two ways: in one way for the divine acceptance itself, which is a gratuitous will of God; in another way for a certain created gift, which formally perfects man and makes him worthy of eternal life." 21 The second of these two ways is the habitual gift bestowed in baptism. But regarding the first of these two ways Thomas writes that "every effect that God works in us from his gratuitous will, by which he accepts us into his

\footnotetext{
19 I cannot refrain from mentioning the backing this provides for saying "for all" rather than "for many" in the words of consecration at the Eucharist. "For many" seems to intend a pure (Donatist?) church.

20 This and the previous quote from Redemptor hominis are taken from Susan Wood, "Solidarity in Grace: The Salvation of Non-Christians" 3 and 5, available at http://www.lonerganresource.com/pdf/contributors/LC2011-05_Wood-Solidarity_in_Grace.pdf.

21 Thomas Aquinas, De veritate, q. 27, a. 5: “Gratia vero gratum faciens ... dupliciter accipitur: uno modo pro ipsa divina acceptatione, quae est gratuita Dei voluntas; alio modo pro dono quodam creato, quod formaliter perficit hominem, et facit eum dignum vita aeterna."
} 
kingdom, pertains to the grace that makes one pleasing" 22 and so to sanctifying grace, the grace of justification. That these latter are to be acknowledged as "sanctifying graces" is explicitly affirmed by Lonergan. ${ }^{23}$ There are other texts in Aquinas that make the same point, including the texts that Jacques Maritain relies on to argue that in the first moral act of every individual justification and elevation to a share in divine life are at stake. ${ }^{24}$ But I am selecting this text because Lonergan emphasizes its importance in Thomas's development. Thomas is on his way toward a theology of actual grace, and it is a theology that would acknowledge that at least some instances of actual grace are also sanctifying graces in the strict sense of the term, in that they include the infusion of supernatural charity. Lonergan interprets Thomas's text precisely in this way. Supernatural habits, and especially of course charity, may not only be infused with baptism but also given as one assents to at least some of the inner promptings of the Holy Spirit by which a person is joined to God in the concrete circumstances of his or her own life; and they may be developed due to fidelity to such promptings.

In De veritate, these graces are not yet "operans" but "cooperans," but in the later Quodlibetum primum the grace of conversion, an actual grace that occurs before and independently of baptism, can be interpreted in no other way than as "gratia operans." 25 And in the Prima secundae actual grace, like habitual grace, is both operative and cooperative, and to both habitual grace and actual grace may be assigned the term "gratia gratum faciens." This may be argued from an exegesis of Summa theologiae, 1-2, q. 111, aa. 1 and 2, and especially from the connection between the two articles. Article 1 asks whether it is appropriate to distinguish grace into gratia gratis data and gratia gratum faciens, grace gratuitously given and grace that makes one pleasing. These two terms occur throughout the development that Lonergan is researching in Grace and Freedom, both prior to Aquinas and in Thomas's own work. But they constantly shift their meaning. The division in the Prima secundae (as contrasted with earlier divisions given the same names both in Aquinas and especially in his predecessors) is a distinction between God's immediate action on the recipient (gratia gratum faciens) and God's use of other people as instruments to lead their fellow human beings to God, for instance, in the preaching of a sermon or homily. The latter is the exclusive meaning of gratia gratis data in article 1 of q. 111. God's immediate action on the person, on the soul, is gratia gratum faciens, and God's use of others is gratia gratis data. In other words, over the course of the history of the use of these two terms, there can be discerned a broadening of the meaning of gratia gratum faciens and a narrowing of the meaning of gratia gratis data. In Thomas's early commentary on the Sentences of Peter Lombard, as Lonergan emphasizes, gratia gratis data referred to every gratuitous gift of God other than the habitual grace infused with baptism, which alone merited the term gratia gratum faciens. But in article 1 of question 111 of the Prima secundae, "gratia gratum faciens" refers to every grace "per quam ipse homo Deo coniungitur," "by which we are joined to God," while "gratia gratis data" refers

\footnotetext{
22 Ibid.: "omnem effectum quem Deus facit in nobis ex gratuita sua voluntate, qua nos in suum regnum acceptat, pertinere ad gratiam gratum facientem." emphasis added.

23 See Bernard Lonergan, Grace and Freedom: Operative Grace in the Thought of St Thomas Aquinas, vol. 1 in Collected Works of Bernard Lonergan, ed. Frederick E. Crowe and Robert M. Doran (Toronto: University of Toronto, 2000) 35.

24 See Jacques Maritain, The Range of Reason (New York: Scribner, 1952). See also Thomas Aquinas, Summa theologiae, 1-2, q. 89, a. 6.

25 The dates of the De veritate are 1256-59 and of the Prima secundae 1271-72. The Quodlibetum primum was written slightly before the Prima secundae.
} 
exclusively to the gift of one person being provided by God to help another and lead that other to God. Obviously, both the habitual grace infused with baptism and the actual grace that is an interior movement caused immediately by God are instances of "gratia gratum faciens," justifying grace, sanctifying grace. Moreover, article 2 goes on to ask whether both the habitual grace infused with baptism and the actual grace that in fact concretely joins a human being to God by a special interior movement are appropriately distinguished into operative and cooperative grace, and the answer is affirmative, with the addendum in the response to the fourth objection that operative grace and cooperative grace in either case, habitual or actual, are really the same grace but distinguished according to effects. In other words, the grace about which article 2 is asking includes every grace whereby human beings are joined to God by God's immediate action, whether that grace be habitual or actual. The history of Thomas's thinking about operative and cooperative grace moves, then, from the unity of gratia gratum faciens and the multiplicity of gratia gratis data in the commentary on the Sentences to the multiplicity of gratia gratum faciens, at least in terms of effects, and the extreme narrowing of the meaning of gratia gratis data in the Prima secundae. The God of the Prima secundae, it would seem, is much more prepared to invite human beings to participate in divine life, and does so in many more ways and with many more people, than was the case with the God of the commentary on the Sentences. At least this is a potential implication of what Aquinas is saying.

The issue would then be one of naming which instances of actual grace qualify also as infusions of charity and thus of sanctifying grace. I turn for at least part of the answer to the passage already cited from Vatican II. What the Holy Spirit offers everyone in a manner known only to God is "the possibility of sharing in this paschal mystery." Paradigmatic of the instances of actual grace that are justifying, that are also sanctifying graces, are those in which the recipient is called to participate in the dynamics of what Christians know as the Law of the Cross, the dispensation whereby the evils of the human race are transformed into a greater good through the loving and non-violent response that returns good for evil. That dialectical posture is for the Lonergan of chapter 20 of Insight a function of supernatural charity. It is by no means limited to the baptized members of Christ's church or even to those outside the church who have in some way become heirs of the positive Wirkungsgeschichte of Christ's historical causality, an influence of which Girard makes so much. ${ }^{26}$

In "De ente supernaturali" Lonergan proposes an original thesis on the meaning of actual grace. Thesis 5 reads, "Interior actual grace consists in vital, principal, and supernatural second acts of the intellect and the will." 27 The key word for my purposes is "principal," and it is Lonergan's interpretation of this word that I find original. Principal acts stand as efficient causes of other acts. In the order of knowledge, principal acts are insights, acts of understanding, whether direct or inverse or reflective or deliberative. In the order of decision, principal acts are the willing of the end, which may be correlated with what the later Lonergan, following Joseph de Finance, will call acts of vertical liberty whereby one moves from one horizon to another, when this movement is a function of

${ }^{26}$ See for instance, René Girard, I See Satan Fall like Lightning, trans. James G. Williams (Maryknoll, NY: Orbis, 2002) 161-69.

27 Lonergan, Early Latin Theology, vol 19 in Collected Works of Bernard Lonergan, trans. Michael G. Shields, ed. Robert M. Doran and H. Daniel Monsour (Toronto: University of Toronto, 2011) 229. 
conversion. Supernatural interior principal acts are acts produced by God immediately in us without any efficient causality on our part: acts of insight and the willing of horizonelevating objectives or ends, where the insight and the willing are gratia operans, to which, by God's grace, we are enabled to assent (gratia cooperans). Among the principal supernatural acts that qualify as actual graces, I propose, are (1) the inverse insight that the violence that returns evil for evil solves nothing, (2) the direct, reflective, and deliberative insights entailed in concrete instances of non-violent resistance and the return of good for evil, and (3) the divinely proposed invitation to participate in a manner of living that concretely and, whether acknowledged as such or not, is patterned on the just and mysterious Law of the Cross. We are here moving into the territory staked out by charity, and charity and sanctifying grace are inseparable. There is never one without the other. The grace-enabled assent to the promptings of the Holy Spirit regarding an act of charity that would return good for evil brings with it the justification or, better, elevation that is meant by gratia gratum faciens. At least these actual graces are also sanctifying graces, and they are so by definition, because of the intimate relation of charity with sanctifying grace. When one takes seriously the theological doctrine that sanctifying grace and charity are participations in and imitations of, respectively, the divine relations of active and passive spiration, one easily grasps that they entail elevation to participation in divine life. ${ }^{28}$

\section{ChARLES TAYLOR'S DISJUNCTIONS}

We may now relate these considerations to Charles Taylor's specification of four disjunctions. These disjunctions sometimes are phrased as found in the contemporary Catholic Church and sometimes are articulated as disjunctions of the church from the North Atlantic secular world in which Taylor lives and works. ${ }^{29}$ As disjunctions of the church from the world, they take the forms of, first, a disjunction of the official hierarchical dimension of the church from the spiritual seeking that prompts people to ask questions that some religious authorities do not want to entertain; second, a related disjunction of the very model of authority that some in the magisterium are holding onto from forms of authority respected in the secular world, where-and here is a point of convergence between Taylor and Lonergan-there is a sense that corresponds to Lonergan's definition of authority as legitimate power, with legitimacy conferred by an authenticity that is acknowledged by the community; ${ }^{30}$ third, a disjunction from the sexual morality and gender equity that contemporaries, and especially younger contemporaries, increasingly accept as correct; and fourth, a disjunction from plural forms of spirituality.

When the disjunctions are articulated so as to highlight division within the church rather than alienation of the church from the secular world, the first disjunction is between "seekers" and "dwellers." Seekers "wish to realize in their life new, more

\footnotetext{
${ }^{28}$ For this theological doctrine, see Bernard Lonergan, The Triune God: Systematics, vol. 12 in Collected Works of Bernard Lonergan, trans. Michael G. Shields, ed. Robert M. Doran and H. Daniel Monsour (Toronto: University of Toronto, 2007) 470-73. For an attempt to articulate the dynamics involved, see Doran, Missions and Processions, chapter 2.

${ }^{29}$ For the sake of convenience I take my references here from George F. McLean, "Introduction: Disjunctions in the 21 $1^{\text {st }}$ Century," in Church and People: Disjunctions in a Secular Age, ed. Charles Taylor, José Casanova, and George F. McLean (Washington, D.C.: The Council for Research in Values and Philosophy, 2012) 1-14.

30 See Bernard Lonergan, "Dialectic of Authority," in A Third Collection, ed. Frederick E. Crowe (Mahwah, NJ: Paulist, 1985) 1-7.
} 
personally authentic, ways of being Christian and Catholic," while dwellers "feel that in the Church all is already clear, well defined, and simply to be followed assiduously." 31

Second, again from an intra-ecclesial perspective, there is a disjunction between "those who bring a modern sense of personal responsibility to church teaching in search of critical convergence" with contemporary trends and exigences and, on the other hand, a conception of "the Church as a jurisdictional authority to which is due obedience" and from which little or no mediation with contemporary society is expected or to be expected.

Third, from the same perspective there is a disjunction between "ethical and moral praxis understood as a human, fallible, and historical or existential achievement" and a "natural law morality built on abstract, unchanging, and universal essences." Most of what Taylor and his students write about this third disjunction addresses divisions in the church over issues of artificial contraception, homosexuality, and the ordination of women.

Fourth, there is a disjunction between "a spirituality open to enrichment by the experiences and spiritualities of the many great religious cultures and civilizations, even the nonreligious" and "a stress on the completeness of the Christian spiritual tradition focused on the Second Person of the Trinity" become incarnate to save us from sin and death.

The situation that prompted Taylor to delineate these disjunctions is one in which "religious engagement and identity in a secular age is no longer expected but instead has become a difficult choice or option." Obviously, there are overlaps from one disjunction to another. Moreover, Taylor is quite clear that the alternatives in at least some of the disjunctions are ideal types, where the term "ideal types" seems to have much the same meaning as the term "models" has in Bernard Lonergan's later terminology: not descriptions about reality or hypotheses about reality but mental constructions that it might be helpful to have at hand when one is trying to describe reality or hypothesize about it. 32

Taylor's delineation of these disjunctions has sparked a great deal of productive scholarly activity. Whether the disjunctions are phrased so as to highlight tensions within the church or in such a way as to articulate the alienation of the church from the secular ambience in which it functions in the North Atlantic context, the four disjunctions may be included under a more all-embracing category, one that names something very serious: the possible disjunction of the church from the very work of God in the contemporary secular world. Whether Taylor would modify his prognosis in the light of the papacy of Francis is not clear. In my view the situation has changed quite radically on the global scene, but it remains much what it was in North America, where bishops in general are far behind the pope in assessing the situation and responding to it.

\footnotetext{
31 McLean, "Introduction" 1. Also all quotes in the next four paragraphs from this source.

32 See Charles Taylor, "The Church Speaks-To Whom?" in Church and People 21. Compare Lonergan: "By a model is not meant something to be copied or imitated. By a model is not meant a description of reality or a hypothesis about reality. It is simply an intelligible, interlocking set of terms and relations that it may be well to have about when it comes to describing reality or to forming hypotheses. As the proverb, so the model is something worth keeping mind when one confronts a situation or tackles a job." Bernard Lonergan, Method in Theology (Toronto: University of Toronto, 1990) xi-xii.
} 
I would like to call for the church's attention to and discernment of invisible missions of both Word and Spirit, divine Truth and divine Love, as the source of the grace that would heal the all-embracing disjunction of the Church from God. Grace is everywhere. The supernatural order is everywhere. The church is called to be its witness everywhere. "It is as though a room were filled with music though one can have no sure knowledge of its source. There is in the world, as it were, a charged field of love and meaning; here and there it reaches a notable intensity; but it is ever unobtrusive, hidden, inviting each of us to join. And join we must if we are to perceive it, for our perceiving is through our own loving." 33

I confess that until the election of Pope Francis I felt a great deal of distrust over the programs that come under the umbrella of "the new evangelization." I regarded these, I think correctly, as instances of what Lonergan calls premature systematization, desperate efforts to pin things down before all the relevant questions have been faced, and even as attempts to substitute another gospel for the gospel of God in Jesus Christ. ${ }^{34}$ The notion of premature systematization and closure, in fact, is in my estimation a more helpful way of understanding Taylor's second and third disjunctions. The issues of authority, gender equity, and sexual ethics are not closed, and they will remain open for some time to come, no matter what church officials say. Eventually some of the church's noninfallible teaching in these regards will be changed. I see hopeful signs of a reorientation of the commitments to evangelization, at least with respect to the exercise of authority and with respect to social and economic justice, in both the elemental meaning of the Pope's dramatic artistry in the exercise of his mission and in the linguistic meaning of many of his homilies and other comments, signs that "new evangelization" might not mean, as I had feared it would, a matter of substituting another gospel for the real one. But the task of reforming the church is enormous, there is much internal resistance to it, some of which is quite well organized and located in hierarchical circles, and there is required, I believe, an explicit if developing horizon for continued progress, for the step-by-step growth that Lonergan called for when he spoke of the perhaps not numerous center at home in both the old and the new, painstaking in working out one by one the transitions to be made, and strong enough to refuse half measures and insist on complete solutions. ${ }^{35}$ One contribution to that horizon, I would propose, would be the acknowledgment of the universal presence of divine healing and elevating grace in the world, including the so-called secular world, through the invisible missions of Word and Spirit, of divine Truth and divine Love, both inside the church and beyond the explicit contours of ecclesial membership. In my view, it is in the realm of these instances of divine grace, of actual graces in the sense treated in the previous section of this paper, actual graces of insights and conversion that promote the Law of the Cross, that we must search as we find a way to a new evangelization.

\footnotetext{
33 Lonergan, Method in Theology 290, with reference to Olivier Rabut, L'expérience religieuse fondamentale (Tournai: Castermann, 1969) 168.

${ }^{34}$ See Bernard Lonergan, Early Works on Theological Method 2, vol. 23 in Collected Works of Bernard Lonergan, trans. Michael G. Shields, ed. Robert M. Doran and H. Daniel Monsour (Toronto: University of Toronto, 2013) 339-40. Among the examples Lonergan lists of premature systematization is clericalism, which, it may be argued, remains today the single greatest obstacle to the implementation of Vatican II reforms. See also Robert M. Doran, "No Other Gospel": Ecclesial Integrity in the Appropriation of the Second Vatican Council," Essay 48 in Essays in Systematic Theology.

35 See Bernard Lonergan, "Dimensions of Meaning," in Collection, vol. 4 in Collected Works of Bernard Lonergan, ed. Frederick E. Crowe and Robert M. Doran (Toronto: University of Toronto, 2008) 245.
} 
The universal mission of the divine Word is affirmed in the prologue to John's Gospel. The Word that became flesh and dwelt among us in the man Christ Jesus, in the socalled visible mission of the Incarnation, that very Word through whom all things were made and in whom is the life that brings light to all, the real light that shines on all who are born into the world-the church is called to point to that Word, and especially to the presence of that Word in all efforts to speak truth in situations of injustice, poverty, and oppression, in attempts to formulate economic, social, and cultural meanings that address these situations with transforming power, and in efforts to mediate faith and contemporary science in the establishment of an intellectual discourse respectful of commitments in both arenas-and so in the advancement of secularizations to be welcomed as well as in the recognition of sacralizations to be fostered.

Next, the divine Love that was poured forth in a palpable mission on Pentecost is present everywhere in the world, as Vatican II and subsequent church teaching, including the teaching of Pope John Paul II, have made abundantly clear. The church is called to acknowledge and foster that gift of divine Love wherever it is found, and to call people together on the basis of a universal gift, a gift that is not restricted to explicit Christian belief but is found in a faith that is born of unqualified love.

The explicit acknowledgment of so-called visible missions of both Word in Incarnation and Spirit at Pentecost are, from this standpoint, the revelation of a divine Truth and a divine Love that are universally given. The genuinely "new" evangelization will be effected as the church has the humility and the discernment to acknowledge these divine gifts wherever they are found, call them for what they are, and encourage cooperation with them. When that happens, we will then be able to develop in great detail a theology of actual grace as an instrument for the elevation of the secular, for the advancement of secularizations to be welcomed and sacralizations to be fostered.

Author: Robert M. Doran, S.J., holds the Emmett Doerr Chair in Catholic Systematic Theology at Marquette University. He specializes in Catholic systematic theology and the philosophy and theology of Bernard Lonergan. He is general editor of The Collected Works of Bernard Lonergan (University of Toronto Press), which will eventually be a set of twenty-five volumes, fourteen of which have already been published. His most recent book is The Trinity in History: A Theology of the Divine Missions, vol. 1: Missions and Processions (Toronto: University of Toronto, 2012).

Email: robert.doran@marquette.edu

(C) Robert M. Doran, 2015 